\title{
The Determinant Factor of the Principal Leadership Solutions in Facing the 21st-Century Learning
}

\author{
Muhammad Saifurrahman ${ }^{1 *}$, Putu Sudira ${ }^{2}$, Rihab Wit Daryono ${ }^{3}$ iD \\ ${ }^{1,2,3}$ Department of Technological and Vocational Education, Yogyakarta State University, Yogyakarta, Indonesia \\ *Corresponding author: muhammadsaifurrahman.2019@student.uny.ac.id
}

\begin{abstract}
Principal leadership is very important in the education and learning efforts of the 21 st-century. This study aims to find determinants of principal leadership solutions in dealing with 21st-century learning in Vocational High Schools (VHS). This research was conducted with a total sample of 64 respondents from the principals, the vice principal for field I-IV, the head of department, and staff. The data analysis used the Exploratory Factor Analysis (EFA) method to test the validity of the constructs and to estimate the reliability of the data. Furthermore, the t-test, One Way Anova, and Games-Howell test were used to test the difference in the average rating based on the characteristics of the respondent's dimensions. The results of the EFA analysis show that seven sub-variables are consisting of 29 determinants of the principal's leadership solution which are identified at $74.266 \%$. The results of the instrument reliability estimation have a reliable level. Based on the different tests using the t-test on the gender dimension and the One Way Anova test on the last position and education dimension, it was concluded that there was no significant difference in the assessment of respondents. The Games-Howell test post-hoc revealed that there were significant differences based on the 29-33 year age dimension and the 5-9-year-old teaching experience dimension.
\end{abstract}

Keywords: Principal, Leadership, Vocational High School

$\begin{array}{lll}\text { History: } & & \text { Publisher: Undiksha Press } \\ \text { Received } & : 24 \text { August } 2020 & \text { Licensed: This work is licensed under } \\ \text { Revised } & : 1 \text { September } 2020 & \text { a Creative Commons Attribution 3.0 License } \\ \text { Accepted } & : 26 \text { September } 2020 & \text { CC (i) () } \\ \text { Published } & : 7 \text { October } 2020 & \end{array}$

\section{INTRODUCTION}

Globalization and the development of Science and Technology have an impact on changing economic systems and patterns of life (Banerjee, 2014; Fox et al., 2019; Grabowski, 2020; Sanderson \& Simons, 2014; Yaya et al., 2020), which demands the human ability to gain opportunities for participation in it (Febrianti et al., 2018; Kolesnichenko et al., 2019). Globalization has entered a new era called the industrial revolution 4.0 (Popkova et al., 2019; Schwab, 2016). In this 21 st-century, education is becoming increasingly important to ensure that students have the skills to learn and innovate (Daryono et al., 2021; Piirto, 2011), use technology and information media (Cetrulo \& Nuvolari, 2019), and can work and survive using life skills and work knowledge (Popkova et al., 2019). The 21st-century is marked by (1) information that is available anywhere and can be accessed at any time, (2) faster computing (Sima et al., 2020), (3) automation that replaces routine jobs (Sima et al., 2020; $\mathrm{Xu}, 2020$ ), and (4) communication that can be done from anywhere and anywhere. The change in the transition from an industrial society to a knowledge-based society affects several aspects both culture and education.

These problems in education can be achieved through learning activities at Vocational High Schools (VHS). Vocational high schools are effective if the skills and knowledge of students are in accordance with the competencies of the world of work (Daryono et al., 2021; Triyono et al., 2020). The academic achievements of students will not run optimally if they do not integrate existing technology. To make this happen, the principal must take his role to bring about change through the school management system and learning environment. To improve the quality of education a principal must be able to improve the performance of teachers and employees, and student achievement and manage all school resources properly 
(Freeman \& Fields, 2020; Hariri et al., 2016; Leithwood et al., 2020; Miller, 2014; Printy, 2010; Sun et al., 2014; Tan, 2018). As a leader, the principal must be able to have a positive influence that causes teachers to be motivated to carry out their duties effectively so that their performance will be better (Lai, 2014). Thus, the principal can make changes in the way of thinking, attitude, behavior he leads (Weinstein \& Muñoz, 2014).

According to the Regulation of the Minister of Education and Culture Number 6 of 2018 concerning the Assignment of Teachers as School Principals, ahead fully carries out managerial main tasks, entrepreneurial development, and supervision of teachers and school education personnel. This aims to develop schools and improve the quality of schools based on 8 national education standards. There are 5 competencies that must be possessed, among others (Yuliawati \& Enas, 2018); (1) personality competence, (2) managerial competence, (3) entrepreneurial competence, (4) supervisory competence, and (5) social competence. Apart from being a leader and guide in the educational process, being an instructional and curricular leader (Abrahamsen et al., 2015; Eckman, 2018; Gawlik, 2018), it is hoped that the principal will become someone who tries and explores new ideas for the system (Yeigh et al., 2019) and a leader in technology mastery (Stringer \& Hourani, 2016). The change in the leadership of the school principal is based on the needs of the industry which is growing rapidly at this time. Because school principals also need to develop their potential as leaders. In this $21 \mathrm{st}-$ century learning, a principal is expected to further diversify educational leadership in learning activities in schools (Gawlik, 2018; Lochmiller, 2015).

Principals in carrying out their duties and functions as school leaders and managers must have a vision and mission (Huang et al., 2020; Liu et al., 2019; Sanchez et al., 2020), as well as a comprehensive and quality-oriented education management strategy. Leadership is an important force in the context of school management (Hallinger \& Liu, 2016; Sleegers et al., 2014), therefore the ability to lead effectively is the key to the success of school organizations (González-Falcón et al., 2020). One of the determining factors for the level of education quality and effectiveness of schools is the leadership of the principal. This is understandable because leadership does not only take initiative but also means management skills (Sebastian et al., 2019; Yeigh et al., 2019), namely the ability to organize and place things according to their place (Khanal et al., 2020; Zheng et al., 2017).

Based on the results of the preliminary study conducted at SMKN 2 Depok and SMKN 2 Wonosari, there are problems with the implementation of 21st-century learning faced by school principals, including student practice equipment facilities at SMK not in accordance with current industry standards. However, there is still a small proportion of school principals in building innovative attitudes that are useful for school development which is still in the sufficient category. This is indicated by the fact that there are still a small number of school principals who have not been able to create a superior program that is different from other schools. This is in line with the results of research by Yuliawati \& Enas (2018) which states that school principals need to improve the management of change and school development towards effective learning organizations then to create innovations that are useful for school development. Therefore, the leadership of the principal is very important in education and learning efforts (Stein et al., 2016) and is able to make good use of opportunities with 21 st-century learning, so that it can create capable student graduates compete in the current era (Hallinger et al., 2018; Marfan \& Pascual, 2018). The leadership opportunities of school principals in the industrial revolution era and 21st-century learning are very influential in creating solutions for school principals in facing the current revolutionary era (Bush et al., 2018). Based on this description, this study aims to find out what factors influence the principal's leadership solution in the face of 21 st-century learning in Vocational High Schools. 


\section{MATERIALS AND METHODS}

This research is a quantitative study using factor analysis techniques. The factor analysis method used is Exploratory Factor Analysis (EFA) to find the determinants of the principal's leadership solution in the face of 21 st-century learning. This study also used parametric statistical tests and comparative analysis to examine differences in the mean value of the dimensions of the character of the study sample in assessing these determinants. Respondents in this study who were the research subjects were the principal (2), the viceprincipal for field I-IV (9), the head of department (23), and staff (30). The number of samples in this study was 64 respondents, namely at VHS 2 Depok there were 35 respondents, and at VHS 2 Wonosari there were 29 respondents.

Table 1. Research Instruments on Determinants of Principal Leadership Solutions

\begin{tabular}{llc}
\hline \multicolumn{1}{c}{ Variable } & \multicolumn{1}{c}{ Sub Variable } & Item \\
\hline & Individual performance-oriented (A) & $1-5$ \\
Principal & Specific justifications for needs in the field (B) & $6-10$ \\
Leadership & Curriculum focus (C) & $11-17$ \\
Solutions in & Training, mentoring and evaluation for educators (D) & $18-23$ \\
$21^{\text {st }}$-Century & Unlimited benchmarks of success (E) & $24-27$ \\
Learning & Sensitivity to the development of the world of work (F) & $28-30$ \\
& Requires adequate facilities and infrastructure (G) & $31-36$ \\
\hline Source: (Huang et al., 2020; Stringer \& Hourani, 2016; Sun et al., 2014; Yuliawati \& Enas, 2018)
\end{tabular}

The grid of school principal leadership challenges in the era of the industrial revolution 4.0 and 21 st-century learning shown in Table 1 . The first data analysis is to prove the construct validity of the determinant factors of the principal's leadership solution in the face of $21^{\text {st }}$-century learning. The initial stage is to ensure data normality based on skewness and kurtosis values ranging from -1.96 to +1.96 and multicollinearity data $<0.90$ (Kaiser et al., 2017; Kline, 2005; ShayesteFar, 2020). Factor analysis uses the Exploratory Factor Analysis (EFA) method to find factors that are able to explain the correlation between the observed variables. The EFA value indicator meets the requirements if the KaiserMeyerOlkin (KMO) value ranges from 0.5-1.0, the Bartlett test value (p <0.00) (Boonk et al., 2020), the Measure of Sampling Adequacy (MSA) ranges from 0.5-1.0, the communality values range from 0.5-1.0, eigenvalues above 1.0 (Reynolds \& Candee, 2019), factor loading ranges from 0.40-1.00 (Chan \& Luk, 2020; Gunuc, 2015; Pala \& Erdem, 2020). The reliability test is accepted if the Cronbach's Alpha value is $\geq 0.70$, Construct Reliability (CR) is more than 0.70, and Average Variance Extracted (AVE) is more than 0.50 (Daryono et al., 2020; Hair et al., 2010; Sudibjo \& Nasution, 2020). Second, the comparative analysis uses parametric statistics to test the mean difference based on the assessment by respondents in each dimension. Parametric statistical analysis used the t-test to look for differences in the average gender dimension (Çetin et al., 2020), while the dimensions of age, position, last education, and length of service used the Games-Howell test Post-hoc because more than two independent samples with ordinal type data of sample sizes are not the same (Hollman et al., 2018; San-Mateo-Valdehíta, 2019). 


\section{RESULTS AND DISCUSSION}

\section{Results}

\section{Preliminary Analysis}

The normality test is useful for determining whether the data collected is normally distributed from the research sample taken. So to find out the normality test, this study calculated based on the skewness and kurtosis values ranging from -1.96 to -1.96 . Overall, there are 36 points offered in the determinant factor of the principal's leadership solution in the face of $21^{\text {st }}$-century learning. Point number 4 has a kurtosis value of 4,552 , so item number 4 is declared invalid for further analysis. Furthermore, the other 35 items obtained skewness values ranging from -0.486 to 0.997 , and kurtosis values ranging from -1.908 to 4.552. So, that 35 items based on this value are declared to be normally distributed. Furthermore, testing the multicollinearity of data on each research variable based on 35 items that passed. Multicollinearity is intended to show a strong correlation between the variables under study so that the items are passed if they have a matrix correlation value is $<0.90$. The study consisted of 7 independent variables given the code A-G. The results of the multicollinearity analysis on seven variables ranged from 0.427 to $0.810(<0.90)$.

\section{Exploratory Factor Analysis (EFA)}

The determinant factor of the principal's leadership solution in the face of $21^{\text {st }}$-century learning is expressed in 35 items that pass tested using construct validity using Exploratory Factor Analysis (EFA) method. The items are declared to pass if they meet the 6 standard criteria for the EFA test results, namely the value of KMO, Bartlett test, MSA, communality, eigenvalues, and factor loading. If the results of the analysis of an item do not meet the criteria, then the item is declared invalid and does not participate in further analysis. In the first order of the EFA analysis of the 35 items analyzed, there were 7 items that did not pass the MSA test $(<0.5)$, namely items number P4, P7, P27, P30, P33, P35, and P36. So that 29 items passed for the EFA test and stated as a determinant factor item on the principal's leadership solution in the face of $21^{\text {st }}$-century learning.

The first output in the EFA analysis is the KaiserMeyer-Olkin (KMO) test and the Bartlett test. The KMO test on 29 determinant factors obtained a value of 0.819 so that the KMO value passed because it was $>0.5$ and the variables used to measure the adequacy of the sample were categorized as satisfactory. While the Bartlett test obtained Approx results. ChiSquare of 1337.698, $\mathrm{df}=406$, Sig. $(\mathrm{p})=0.00$. The significance value is 0.00 which indicates that the value has a strong correlation. The next output is the eigenvalue test result and the total variance explained. The total variance explained table shows the factors that are formed from the existing variables. The simplification of the existing variables is done by looking at the total eigenvalue which has a value of $>1$ which is seen as a new factor being formed (see Table 2).

Table 2. Total Variance Explained on Determinants of Principal Leadership

\begin{tabular}{ccccccc}
\hline \multirow{2}{*}{ Factor } & \multicolumn{3}{c}{ Initial Eigenvalues } & \multicolumn{2}{c}{ Rotation Sums of Squared Loadings } \\
\cline { 2 - 7 } & Total & \% of Variance & Cumulative $\%$ & Total & \% of Variance & Cumulative \% \\
\hline 1 & 11.859 & 40.894 & 40.894 & 5.349 & 18.444 & 18.444 \\
2 & 2.474 & 8.529 & 49.423 & 3.991 & 13.760 & 32.205 \\
3 & 2.270 & 7.828 & 57.252 & 3.042 & 10.490 & 42.695 \\
4 & 1.510 & 5.205 & 62.457 & 2.675 & 9.224 & 51.919 \\
5 & 1.216 & 4.192 & 66.649 & 2.614 & 9.013 & 60.932 \\
6 & 1.131 & 3.898 & 70.547 & 2.020 & 6.966 & 67.898 \\
7 & 1.079 & 3.719 & 74.266 & 1.847 & 6.368 & 74.266 \\
\hline
\end{tabular}


Based on Table 2, The results of the Total Variance Explained analysis reveal 7 determinants of the principal's leadership solution, this is formed because it has an eigenvalue $>1.00$. Factor 1 has an eigenvalue of 11.859 and is able to explain the variance of $40.894 \%$. While factor 2 has an eigenvalue of 2.474 and is able to explain the variance of $8.529 \%$ and then up to the seventh factor. So that the overall research variables in determining the factors for the principal's leading solution to face $21^{\text {st }}$-century learning can be identified as much as $74.266 \%$. Figure 1 shows the scree plot of the results of the eigenvalue analysis on the component number.

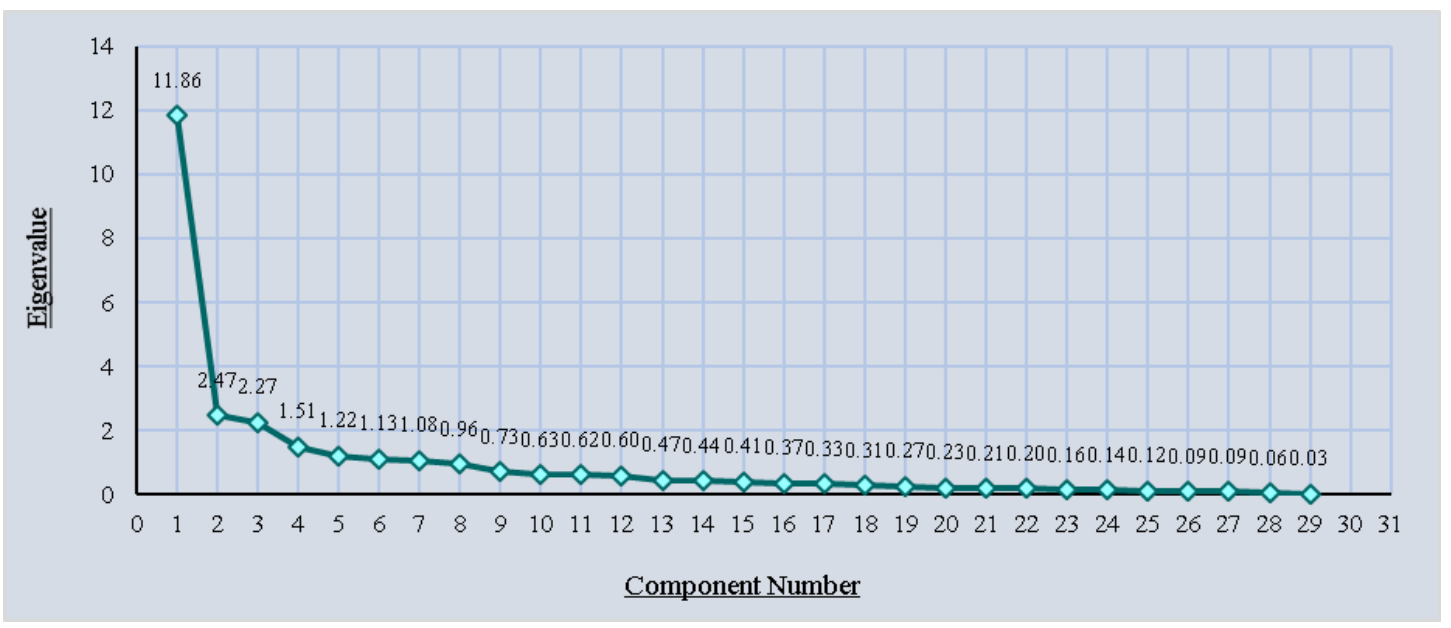

Figure 1. Scree Plot of the Determinant Factor of the Principal Leadership Solutions

Table 3. The EFA Analysis of the Determinant Factor of the Principal Leadership Solutions

\begin{tabular}{|c|c|c|c|c|c|c|c|c|c|c|}
\hline \multirow{2}{*}{$\begin{array}{c}\text { Variabl } \\
\text { e }\end{array}$} & \multirow{2}{*}{ Item } & \multirow[t]{2}{*}{ MSA } & \multirow[t]{2}{*}{ Comm. } & \multicolumn{7}{|c|}{ Factor Loading } \\
\hline & & & & 1 & 2 & 3 & 4 & 5 & 6 & 7 \\
\hline \multirow[t]{4}{*}{ A } & P1 & 0.850 & 0.759 & & 0.632 & & & & & \\
\hline & $\mathrm{P} 2$ & 0.842 & 0.711 & & 0.661 & & & & & \\
\hline & P3 & 0.781 & 0.743 & & 0.758 & & & & & \\
\hline & P5 & 0.845 & 0.747 & & 0.462 & & & & & \\
\hline \multirow[t]{4}{*}{ B } & P6 & 0.878 & 0.710 & & & & 0.686 & & & \\
\hline & P8 & 0.583 & 0.686 & & & & 0.758 & & & \\
\hline & P9 & 0.841 & 0.765 & & & & 0.616 & & & \\
\hline & P10 & 0.737 & 0.765 & & & & 0.555 & & & \\
\hline \multirow[t]{7}{*}{$\mathrm{C}$} & P11 & 0.852 & 0.773 & & & 0.616 & & & & \\
\hline & P12 & 0.816 & 0.701 & & & 0.627 & & & & \\
\hline & P13 & 0.769 & 0.769 & & & 0.821 & & & & \\
\hline & P14 & 0.818 & 0.751 & & & 0.737 & & & & \\
\hline & P15 & 0.782 & 0.806 & & & 0.837 & & & & \\
\hline & P16 & 0.783 & 0.713 & & & 0.767 & & & & \\
\hline & P17 & 0.859 & 0.684 & & & 0.573 & & & & \\
\hline \multirow[t]{6}{*}{$\mathrm{D}$} & P18 & 0.846 & 0.673 & & & & & 0.513 & & \\
\hline & P19 & 0.781 & 0.690 & & & & & 0.516 & & \\
\hline & P20 & 0.905 & 0.603 & & & & & 0.433 & & \\
\hline & $\mathrm{P} 21$ & 0.736 & 0.790 & & & & & 0.792 & & \\
\hline & $\mathrm{P} 22$ & 0.837 & 0.755 & & & & & 0.709 & & \\
\hline & $\mathrm{P} 23$ & 0.817 & 0.737 & & & & & 0.654 & & \\
\hline E & $\mathrm{P} 24$ & 0.791 & 0.831 & & & & & & & 0.752 \\
\hline
\end{tabular}




\begin{tabular}{ccccccccccc}
\hline $\begin{array}{c}\text { Variabl } \\
\text { e }\end{array}$ & Item & MSA & Comm. & \multicolumn{7}{c}{ Factor Loading } \\
\cline { 6 - 10 } & & & $\mathbf{1}$ & $\mathbf{2}$ & $\mathbf{3}$ & $\mathbf{4}$ & $\mathbf{5}$ & $\mathbf{6}$ & $\mathbf{7}$ \\
\hline & P25 & 0.789 & 0.920 & & & & & & & 0.697 \\
F & P26 & 0.798 & 0.840 & & & & & & 0.813 \\
& P28 & 0.823 & 0.726 & & & & & & 0.670 & \\
G & P29 & 0.896 & 0.754 & & & & & & 0.593 & \\
& P31 & 0.848 & 0.805 & 0.798 & & & & & & \\
& P32 & 0.770 & 0.716 & 0.740 & & & & & & \\
& P34 & 0.906 & 0.616 & 0.630 & & & & & & \\
\hline
\end{tabular}

MSA was used to measure the relationship between variables and the suitability of factor analysis. The value of communalities shows how strongly the variables affect the determinants of the principal's leadership solution. The next output that is seen is a rotated component matrix. This table shows the loading factor for each factor. The principle of EFA analysis is that each item can be correlated with all factors, but a good item only has a high loading factor on the factor it measures, which is more than 0.4. MSA test results, communalities, and factor loading are shown in Table 3. Furthermore, to assess the feasibility of each variable for factor analysis used the MSA criterion. In Table 3, the MSA results range from 0.583-0.906. This shows that 29 items have met the criteria for the MSA (>0.5). The value of communalities on each item ranges from 0.603-0.920, this shows that each item has influenced more than $50 \%$ of the determinants of the principal's leadership solution. The results of the loading factor analysis on 29 items ranged from 0.433 to 0.837 so that each item could correlate with all determinants of school principal leadership.

\section{Instrument Reliability}

After testing the model fit in the EFA analysis, there is an evaluation that must be done, namely the reliability test. Reliability measurement with Cronbach's Alpha cannot measure the unidimensionality of the multi-indicator construct. So it takes reliability testing with Construct Reliability (CR) and Average Variance Extracted (AVE) to assess the reliability of the measurement model. Construct reliability is a measure of the internal consistency of the indicators of a constructed variable that shows degrees in the formed variables. Average Variance Extract is a measure of how much the variance of the indicator is extracted by the formed variables. The results of the instrument reliability test showed that the overall CA results were 0.923 (>0.70), while CR obtained results between 0.751-0.944 $(>0.70)$ and AVE obtained results between 0.514-0.6637 (>0.50). So that the instrument for determining the factors in the principal's leadership solution has a good level of reliability (see Table 4).

Table 4. Reliability of Instrument Data

\begin{tabular}{lcccc}
\hline \multicolumn{1}{c}{ Variable } & CA & Overall CA & CR AVE \\
\hline Individual performance-oriented (A) & 0.8 & \multirow{2}{*}{0.923} & 0.944 & 0.51 \\
& 02 & & & 4 \\
Specific justifications for needs in the field (B) & 0.7 & & 0.751 & 0.53 \\
& 07 & & 6 \\
Curriculum focus (C) & 0.7 & & 0.880 & 0.51 \\
& 80 & & & 5 \\
Training, mentoring and evaluation for educators (D) & 0.8 & & 0.778 & 0.49 \\
& 10 & & & 3 \\
Unlimited benchmarks of success (E) & 0.8 & & 0.799 & 0.57 \\
& 66 & & & 0 \\
\hline
\end{tabular}




\begin{tabular}{lcccc}
\hline Variable & CA & Overall CA & CR AVE \\
\hline Sensitivity to the development of the world of work (F) & 0.7 & & 0.791 & 0.63 \\
& 56 & & 7 \\
& 0.8 & & 0.768 & 0.52 \\
Requires adequate facilities and infrastructure (G) & 28 & & 7 \\
\hline
\end{tabular}

\section{Assessment of Principal Leadership Solutions: Respondents' Perceptions}

The first perception towards the assessment of the principal's leadership solution is by the respondent with the gender dimension. The different test on the average assessment of this dimension uses the t-test because it is an independent sample with normally distributed data. Based on the t-test output, it is known that the $\mathrm{t}$-value $=0.546\left(<\mathrm{t}_{62}=1.999\right)$ and Sig. $(2$ tailed) of $0.587(>0.05)$. So it is concluded that there is no significant difference between the average results of the assessment of the principal's leadership solutions in the face of $21^{\text {st }}$ century learning based on respondents on the gender dimension. The One Way Anova test in this study was used to test on average whether there was a significant difference between the 4 or 5 groups of independent variables on the determinants of the principal's leadership solution to the perception of the respondent's assessment. The next analysis of the difference test, namely the dimensions of the position and the last education used parametric statistics with the One Way Anova test because the data were normally distributed.

Based on the results of the analysis of different tests on the position dimensions of the respondents' assessment, the calculated $F_{\text {value }}=0.416\left(<F_{3 ; 60}=2.76\right)$ and the Sig. obtained $P_{\text {value }}=0.742(>0.05)$. In the last education dimension, the calculated $\mathrm{F}$ value $=0.595\left(<\mathrm{F}_{3: 60}\right.$ $=2.76)$ and the Sig. obtained $P_{\text {value }}=0.963(>0.05)$. So it can be concluded that there is no significant difference in the average results on the dimensions of position and last education in assessing the solutions of principals' leadership in facing $21^{\text {st }}$-century learning. If the test results show that a difference is accepted, then the Post-Hoc test is not performed. The One Way Anova test results show a significant difference, then the next test is to see which groups are different using the Games-Howell test with test results showing different variants and different sample sizes. The results of the analysis of the mean difference test on the dimensions of age and teaching experience used parametric statistics with the Games-Howell Post-Hoc test.

Based on the results of the analysis of different tests on the dimensions of age against the respondents' assessment, the calculated $F_{\text {value }}=4.160\left(>F_{4 ; 59}=2.53\right)$ and the Sig. obtained $P_{\text {value }}=0.005(<0.05)$. In the dimension of teaching experience, the value of $\mathrm{F}_{\text {value }}=3.746$ $\left(>\mathrm{F}_{4 ; 59}=2.53\right)$ and the Sig. obtained $P_{\text {value }}=0.009(<0.05)$. So it can be concluded that there are significant differences in the average results in the dimensions of age and teaching experience in assessing the principal's leadership solutions in the face of $21^{\text {st }}$-century learning. The average age is the group aged 29-33 (2.917), which is different from other groups. Whereas in the dimension of teaching experience, the Games-Howell test showed a difference in assessment in the 5-9 years teaching group (2.945).

\section{Assessment of the Principal's Leadership Solution in the Face of $21^{\text {st }}$-Century Learning Based on the Position Dimension}

Overall the results of data acquisition from 7 sub-variables of determinants of the principal's leadership solution ranged from 3.328 to 3.266 (from 4.0). The dominant sub variable insensitivity to the development of the world of work $(F)$ with a total of 2 points, namely the Principal advising teachers and stakeholders in emphasizing the adaptive capacity of graduates, to changes in the industrial environment, and the Principal instructing stakeholders, teachers, and staff to implement education that emphasizes the needs of industry (see Figure 2). 
The factors that determine the principal's leadership solution in $21^{\text {st }}$-century learning are 29 factors from 7 variables. The first variable is oriented towards individual performance in the world of work which consists of 4 factors which include the principle of implementing competency-based education in accordance with the world of work. The second variable is a special justification for real needs in the field consisting of 4 factors which include the principal implementing learning activities according to the latest curriculum, holding a teaching factory program in schools with stakeholders, collaborating and identifying the competency needs needed by the industry. The third variable, namely the curriculum focuses on the affective and cognitive aspects of psychomotor, consists of 7 factors which include making innovations in improving student skills, conducting psychomotor assessments, increasing competence with the latest learning.

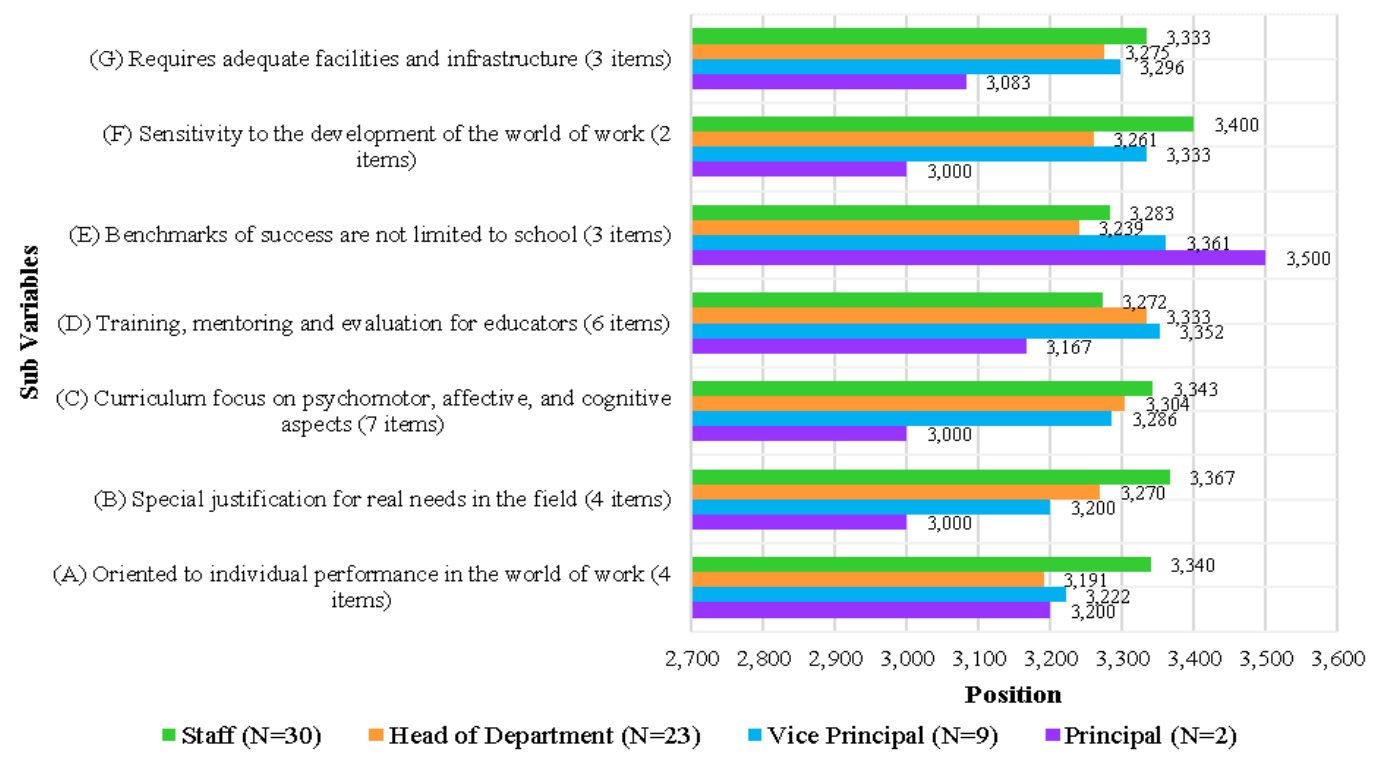

Figure 2. The Results of an Assessment of the Principal's Leadership Solution in the Face of $21^{\text {st }}$-Century Learning Based on the Position Dimension

The fourth variable, namely training, mentoring, and evaluation to educators consists of 6 factors which include increasing teacher competence through education and training, evaluation of teacher training results, innovating in learning. The fifth variable, namely the benchmarks for success is not limited to schools, consists of 3 factors which include the implementation of an apprenticeship program, the implementation of the multi-entry-multi exit (MEME) program, developing the professional abilities of school personnel. The sixth variable, namely sensitivity to the development of the world of work, consists of 2 factors which include advising and instructing teachers and stakeholders in emphasizing the adaptive capacity of graduates to industrial needs. The seventh variable, namely adequate facilities and infrastructure, consists of 3 factors which include implementing development projects in schools, ensuring the completeness of facilities and infrastructure according to the need for work, and improving quality services.

\section{Discussion}

There are 29 of the 36 points offered regarding the determinants of the principal's leadership solution in the face of 21 st-century learning according to proving construct validity and estimating item reliability. The 7 points that have failed include: The principal carries out certification of teacher eligibility as a teacher (4); The principal instructed the staff 
to carry out learning on the aspects of hard and soft skills (7); Principals need to allow students to undertake distance education in several vocational subjects that can be carried out independently (27); The principal instructs the teaching staff in designing learning activities that are relevant to the real world (30); The principal tries to improve the appearance of the school through various kinds of thinking about new programs (33); Principals can provide various Office Stationery needed to support smooth administration (35); The principal develops the school website as a means of delivering school information globally (36).

Furthermore, for the dominant indicator, namely the principle applies competencybased education that is in accordance with the world of work and the principal recommends that learning materials be obtained from various sources. This implies that school principals must have competence in preparing school planning, developing organizations, leading schools, managing change, creating school culture, managing teachers and staff, managing infrastructure, managing school relations and industry, student development, management of curriculum development, the use of advances in information technology, and monitoring and evaluation have been implemented properly so as to improve school competence in $21 \mathrm{st}-$ century learning. This research is in line with the results of research by previous research which states that in addition to having management competence, the principal must also have supervision in dealing with 21st-century learning (Yuliawati \& Enas, 2018).

Based on the variables oriented to individual performance in the world of work, the principal needs to conduct competency tests for teachers on a regular basis and provide training for teachers to develop learning activities in schools for the better. This is consistent with other research to provide services for education and training for teachers and staff to support school administration and learning in the 21st-century (Huang et al., 2020; Yeigh et al., 2019). Furthermore, in the specific justification variable on real needs in the field, school principals need to work together to hold a teaching factory program in schools with education stakeholders vocational and identify competency requirements that are required by the industry. In the curriculum focus variable, the principal needs to focus on affective and cognitive psychomotor aspects. Curriculum development must be in accordance with industrial technology developments and the needs of the world of work so that student competencies are ready to support skills for work.

School principals need to provide training, mentoring, and evaluation to educators to create responsive, reliable, and adaptive educators. This is consistent with previous research that school principals need to make training that is carried out after planning and socialization and assist teachers in solving problems in the 21st-century learning process (González-Falcón et al., 2020). In addition, to give appreciation to educators who have innovations in improving school quality. In measuring success indicators, school principals need to develop the professional abilities of school personnel, for example by sending teachers to attend various training and seminars. This is in line with research for certification that determines the eligibility of teachers as teachers (Sun et al., 2014). In addition, other factors reveal that school principals need to make efforts to improve school services to improve quality so that the completeness of school facilities and infrastructure can be fulfilled (Stringer \& Hourani, 2016; Sun et al., 2014).

There are different indicators of the previous research, in terms of the attributes, behaviors, perceptions, and attitudes of these principals having an impact on student achievement and these findings in helping teachers change their teaching and make it more effective, but have not been explained in trying to do this (Yeigh et al., 2019). This research contributes to the pursuit of these solutions, that principals must plan work programs for training and evaluating teacher performance so that they can improve teacher competence through education and training and assist teachers in solving problems in 21st-century learning faced in the 21st-century learning process and has an impact on increasing student 
competency achievement. Our research reveals seven aspects of principal determinants that are considered important as leadership solutions in 21st-century learning. This complements the limitations of the results of research which did not study how the characteristics of the principal's background, such as experience and training for staff and teachers, and school contextual characteristics predict principal typology and principal effectiveness in instructional leadership or organizational management (Sebastian et al. (2019). In our study, it was revealed by all research variables.

\section{CONCLUSION}

In carrying out his leadership function, the principal must manage and foster the school through good administration and management activities. In this case, the principal functions as a supervisor, coach, and evaluation of all educational activities carried out in schools. So that the guidance of school principals through the implementation of supervision of efforts to increase teacher competence in carrying out the learning process can take place optimally. Most importantly, the findings of this researcher recommend to school principals to improve the quality of education in vocational schools in the implementation of $21 \mathrm{st}-$ century learning. These efforts can be measured through the attributes of how the principal's performance in individual performance orientation, adjustment of needs in the field, curriculum focus, training, mentoring and evaluation for educators, sensitivity to developments in the world of work, as well as improving facilities and infrastructure for $21 \mathrm{st}-$ century learning readiness. Such solutions can not only be used by school principals in vocational schools but other schools as a measure of the school's ability to align with the broader vision and goals. So that preparation in optimizing 21 st-century learning will run more effectively. In this case, we can say that school leadership will be effective if the cooperation of all stakeholders to take advantage of harmony, ability, and involvement goes together. Future research is recommended to focus on how these attributes of readiness can contribute and their influence on knowledge in the field of school leadership, in addition to determining the determinants of principals in 21 st-century learning.

\section{REFERENCES}

Abrahamsen, H., Aas, M., \& Hellekjær, G. O. (2015). How do principals make sense of school leadership in Norwegian reorganised leadership teams? School Leadership \& Management, 35(1), 62-78. https://doi.org/10.1080/13632434.2014.992775.

Banerjee, R. (2014). Human capital, technological progress and trade: What explains India's long run growth? Journal of Asian Economics, 30(1), 1-17. https://doi.org/10.1016/j.asieco.2013.12.003.

Boonk, L. M., Gijselaers, H. J. M., Ritzen, H., \& Brand-Gruwel, S. (2020). Student-perceived parental involvement as a predictor for academic motivation in vocational education and training (VET). Journal of Vocational Education \& Training, 1-23. https://doi.org/10.1080/13636820.2020.1745260.

Bukit, M. (2014). Strategi dan inovasi pendidikan kejuruan dari kompetensi ke kompetisi. Alfabeta.

Bush, T., Abdul Hamid, S., Ng, A., \& Kaparou, M. (2018). School leadership theories and the Malaysia Education Blueprint: Findings from a systematic literature review. International Journal of Educational Management, 32(7), 1245-1265. https://doi.org/10.1108/IJEM-06-2017-0158. 
Çetin, Z., Özözen Danacı, M., \& Kuzu, A. (2020). The effect of psychological violence on preschool teachers' perceptions of their performance. South African Journal of Education, 40(1), 1-11. https://doi.org/10.15700/saje.v40n1a1738.

Cetrulo, A., \& Nuvolari, A. (2019). Industry 4.0: Revolution or hype? Reassessing recent technological trends and their impact on labour. Journal of Industrial and Business Economics, 46(3), 391-402. https://doi.org/10.1007/s40812-019-00132-y.

Chan, C. K. Y., \& Luk, L. Y. Y. (2020). Development and validation of an instrument measuring undergraduate students' perceived holistic competencies. Assessment \& Evaluation in Higher Education, 1-16. https://doi.org/10.1080/02602938.2020.1784392.

Daryono, R. W., Hariyanto, V. L., \& Usman, H. (2020). Factor analysis: Competency framework for measuring student achievements of architectural engineering education in Indonesia. REID (Research and Evaluation in Education), 6(2), 98-108. https://doi.org/10.21831/reid.v6i2.32743.

Daryono, R. W., Rochmadi, S., \& Hidayat, N. (2021). Development and validation of videobased learning media to increase competency achievement in civil engineering education. Journal of Physics: Conference Series, 1833(1-10), 012022. https://doi.org/10.1088/1742-6596/1833/1/012022.

Eckman, E. W. (2018). A Case Study of the Implementation of the Co-Principal Leadership Model. Leadership and Policy in Schools, 17(2), 189-203. https://doi.org/10.1080/15700763.2016.1278243.

Febrianti, R. A. M., Haizam Mohd Saudi, M., Kaniawati, K., \& Hermina, N. (2018). Transformation of Digital Marketing in the 4.0 Industry Revolution: A Study on Batik MSMEs. International Journal of Engineering \& Technology, 7(4.34), 352-357. https://doi.org/10.14419/ijet.v7i4.34.25779.

Fox, A., Feng, W., \& Asal, V. (2019). What is driving global obesity trends? Globalization or "modernization"? Globalization and Health, 15(1), 1-16. https://doi.org/10.1186/s12992-019-0457-y.

Freeman, G. T., \& Fields, D. (2020). School leadership in an urban context: Complicating notions of effective principal leadership, organizational setting, and teacher commitment to students. International Journal of Leadership in Education, 1-21. https://doi.org/10.1080/13603124.2020.1818133.

Gawlik, M. (2018). Instructional leadership and the charter school principal. School Leadership \& Management, 1-27. https://doi.org/10.1080/13632434.2018.1439467.

González-Falcón, I., García-Rodríguez, M. P., Gómez-Hurtado, I., \& Carrasco-Macías, M. J. (2020). The importance of principal leadership and context for school success: Insights from '(in)visible school.' School Leadership \& Management, 40(4), 248265. https://doi.org/10.1080/13632434.2019.1612355.

Grabowski, R. (2020). What factors influence the quality of governance institutions? An Asian perspective. Journal of Asian Economics, 70(1), 1-12. https://doi.org/10.1016/j.asieco.2020.101238.

Gunuc, S. (2015). Student engagement scale: Development, reliability and validity. Assessment \& Evaluation in Higher Education, 40(4), 1-24. https://doi.org/10.1080/02602938.2014.938019.

Hair, J. F., Black, W. C., Babin, B. C., \& Anderson, R. E. (2010). Multivariate data analysis (Seventh Edition). Englewood Cliffs, NJ.

Hallinger, P., Hosseingholizadeh, R., Hashemi, N., \& Kouhsari, M. (2018). Do beliefs make a difference? Exploring how principal self-efficacy and instructional leadership impact teacher efficacy and commitment in Iran. Educational Management 
Administration $\quad \& \quad$ Leadership, $\quad 46(5), \quad 800-819$. https://doi.org/10.1177/1741143217700283.

Hallinger, P. P., \& Liu, D. S. (2016). Leadership and teacher learning in urban and rural schools in China: Meeting the dual challenges of equity and effectiveness. International Journal of Educational Development, 51(1), 1-10. https://doi.org/10.1016/j.ijedudev.2016.10.001.

Hariri, H., Monypenny, R., \& Prideaux, M. (2016). Teacher-perceived principal leadership styles, decision-making styles and job satisfaction: How congruent are data from Indonesia with the Anglophile and Western literature? School Leadership \& Management, 36(1), 41-62. https://doi.org/10.1080/13632434.2016.1160210.

Hollman, A., Bice, M. R., Ball, J., Bickford, N., Shafer, A. B., \& Bickford, S. (2018). A comparison of scholarly productivity among current professors who obtained terminal degrees. American Journal of Distance Education, 32(4), 17. https://doi.org/10.1080/08923647.2018.1511514.

Huang, F., Teo, T., \& Zhou, M. (2020). Chinese students' intentions to use the Internet-based technology for learning. Educational Technology Research and Development, 68(1), 575-591. https://doi.org/10.1007/s11423-019-09695-y.

Huang, T., Hochbein, C., \& Simons, J. (2020). The relationship among school contexts, principal time use, school climate, and student achievement. Educational Management Administration \& Leadership, 48(2), 305-323. https://doi.org/10.1177/1741143218802595.

Kaiser, M., Bauer, J. M., \& Sousa-Poza, A. (2017). Does unemployment lead to a less healthy lifestyle? Applied Economics Letters, 24(12), 815-819. https://doi.org/10.1080/13504851.2016.1231888.

Khanal, J., Perry, F., \& Park, S.-H. (2020). Leadership practices of principals of highperforming community high schools: Evidence from Nepal. Educational Management Administration \& Leadership, 48(6), 1026-1045. https://doi.org/10.1177/1741143219884076.

Kline, R. B. (2005). Principles and practice of structural equation modeling. The Guilford Press.

Kolesnichenko, E. A., Radyukova, Y. Y., \& Pakhomov, N. N. (2019). The Role and Importance of Knowledge Economy as a Platform for Formation of Industry 4.0. In E. G. Popkova, Y. V. Ragulina, \& A. V. Bogoviz (Eds.), Industry 4.0: Industrial Revolution of the 21st Century (Vol. 169, pp. 73-82). Springer International Publishing. https://doi.org/10.1007/978-3-319-94310-7_7.

Lai, E. (2014). Principal leadership practices in exploiting situated possibilities to build teacher capacity for change. Asia Pacific Education Review, 15(2), 165-175. https://doi.org/10.1007/s12564-014-9314-0.

Leithwood, K., Harris, A., \& Hopkins, D. (2020). Seven strong claims about successful school leadership revisited. School Leadership \& Management, 40(1), 5-22. https://doi.org/10.1080/13632434.2019.1596077.

Liu, L., Du, X., Zhang, Z., \& Zhou, J. (2019). Effect of problem-based learning in pharmacology education: A meta-analysis. Studies in Educational Evaluation, 60, 4358. https://doi.org/10.1016/j.stueduc.2018.11.004.

Lochmiller, C. R. (2015). Exploring Principal Leadership for Math and Science. Journal of School Leadership, 25(1), 24-53. https://doi.org/10.1177/105268461502500102.

Marfan, J., \& Pascual, J. (2018). Comparative study of school principals' leadership practices: Lessons for Chile from a cross-country analysis. Educational Management Administration \& Leadership, 46(2), 279-300. https://doi.org/10.1177/1741143217732792. 
Miller, P. (2014). What is a Principal's Quality Mark? Issues and Challenges in Leadership Progression among Primary Teachers in Jamaica. Research in Comparative and International Education, 9(1), 126-136. https://doi.org/10.2304/rcie.2014.9.1.126.

Pala, F. K., \& Erdem, M. (2020). Development of a participation style scale for online instructional discussions. Educational Technology Research and Development, 68(6), 3213-3233. https://doi.org/10.1007/s11423-020-09817-x.

Piirto, J. (2011). Creativity for 21st century skills: How to embed creativity into the curriculum. Sense Publ.

Popkova, E. G., Ragulina, Y. V., \& Bogoviz, A. V. (Eds.). (2019). Industry 4.0: Industrial Revolution of the 21st Century (Vol. 169). Springer International Publishing. https://doi.org/10.1007/978-3-319-94310-7.

Printy, S. (2010). Principals' influence on instructional quality: Insights from US schools. School Leadership \& Management, 30(2), 111-126. https://doi.org/10.1080/13632431003688005.

Reynolds, A. J., \& Candee, A. J. (2019). Dimensionality and Predictive validity of the Classroom Learning Activities Checklist in Prekindergarten. Educational Assessment, Evaluation and Accountability, 31(4), 381-407. https://doi.org/10.1007/s11092-01909306-7.

Sanchez, J. E., Paul, J. M., \& Thornton, B. W. (2020). Relationships among teachers' perceptions of principal leadership and teachers' perceptions of school climate in the high school setting. International Journal of Leadership in Education, 1-21. https://doi.org/10.1080/13603124.2019.1708471.

Sanderson, S. W., \& Simons, K. L. (2014). Light emitting diodes and the lighting revolution: The emergence of a solid-state lighting industry. Research Policy, 43(10), 1730-1746. https://doi.org/10.1016/j.respol.2014.07.011.

San-Mateo-Valdehíta, A. (2019). Learning word class in a second language through vocabulary learning activities: Definition-choosing, gap-filling, and sentence-writing. Journal of Spanish Language Teaching, 6(1), 1-15. https://doi.org/10.1080/23247797.2019.1590001.

Schwab, K. (2016). The Fourth Industrial Revolution. World Economic Forum.

Sebastian, J., Allensworth, E., Wiedermann, W., Hochbein, C., \& Cunningham, M. (2019). Principal Leadership and School Performance: An Examination of Instructional Leadership and Organizational Management. Leadership and Policy in Schools, 18(4), 591-613. https://doi.org/10.1080/15700763.2018.1513151.

ShayesteFar, P. (2020). A model of interplay between student English achievement and the joint affective factors in a high-stakes test change context: Model construction and validity. Educational Assessment, Evaluation and Accountability, 32(3), 335-371. https://doi.org/10.1007/s11092-020-09326-8.

Sima, V., Gheorghe, I. G., Subić, J., \& Nancu, D. (2020). Influences of the Industry 4.0 Revolution on the Human Capital Development and Consumer Behavior: A Systematic Review. Sustainability, 12(10), 1-28. https://doi.org/10.3390/su12104035.

Sleegers, J. C. P., E.J. Thoonen, E., J. Oort, F., \& T.D. Peetsma, T. (2014). Changing classroom practices: The role of school-wide capacity for sustainable improvement. Journal of Educational Administration, 52(5), 617-652. https://doi.org/10.1108/JEA11-2013-0126.

Stein, K. C., Macaluso, M., \& Stanulis, R. N. (2016). The Interplay between Principal Leadership and Teacher Leader Efficacy. Journal of School Leadership, 26(6), 10021032. https://doi.org/10.1177/105268461602600605. 
Stringer, P., \& Hourani, R. B. (2016). Transformation of roles and responsibilities of principals in times of change. Educational Management Administration \& Leadership, 44(2), 224-246. https://doi.org/10.1177/1741143214549971.

Sudibjo, N., \& Nasution, R. A. (2020). Work environment, work motivation and organizational culture in influencing teachers' performance. Jurnal Pendidikan Dan Pengajaran, 53(3), 276. https://doi.org/10.23887/jpp.v53i3.28533 .

Sun, H., Wang, X., \& Sharma, S. (2014). A study on effective principal leadership factors in China. International Journal of Educational Management, 28(6), 716-727. https://doi.org/10.1108/IJEM-11-2013-0173.

Tan, C. Y. (2018). Examining school leadership effects on student achievement: The role of contextual challenges and constraints. Cambridge Journal of Education, 48(1), 21-45. https://doi.org/10.1080/0305764X.2016.1221885.

Triyono, B. M., Mohib, N., Kassymova, G. K., Pratama, G. N. I. P., Adinda, D., \& Arpentieva, M. R. (2020). The Profile Improvement of Vocational School Teachers' Competencies. Vysshee Obrazovanie v Rossii = Higher Education in Russia, 29(2), 151-158. https://doi.org/10.31992/0869-3617-2020-29-2-151-158.

Weinstein, J., \& Muñoz, G. (2014). When duties are not enough: Principal leadership and public or private school management in Chile ${ }^{1}$. School Effectiveness and School Improvement, 25(4), 651-670. https://doi.org/10.1080/09243453.2013.792850.

$\mathrm{Xu}, \mathrm{L}$. D. (2020). Industry 4.0-Frontiers of fourth industrial revolution. Systems Research and Behavioral Science, 37(4), 531-534. https://doi.org/10.1002/sres.2719.

Yaya, S., Otu, A., \& Labonté, R. (2020). Globalisation in the time of COVID-19: Repositioning Africa to meet the immediate and remote challenges. Globalization and Health, 16(1), 1-7. https://doi.org/10.1186/s12992-020-00581-4.

Yeigh, T., Lynch, D., Turner, D., Provost, S. C., Smith, R., \& Willis, R. L. (2019). School leadership and school improvement: An examination of school readiness factors. School Leadership \& Management, 39(5), 434-456. https://doi.org/10.1080/13632434.2018.1505718.

Yuliawati, \& Enas. (2018). Implementasi Kompetensi Kepala Sekolah Dalam Meningkatkan Kompetensi Guru. Indonesian Journal of Education Management and Administration Review, 2(2), 318-324.

Zheng, Q., Li, L., Chen, H., \& Loeb, S. (2017). What Aspects of Principal Leadership Are Most Highly Correlated with School Outcomes in China? Educational Administration Quarterly, 53(3), 409-447. https://doi.org/10.1177/0013161X17706152. 